\title{
Guava: phytochemical composition of a potential source of antioxidants for cosmetic and/or dermatological applications
}

\author{
Bruna Galdorfini Chiari-Andréo ${ }^{1}$, Eliane Trovatti ${ }^{2,3}$, Joana Marto ${ }^{4}$, Maria Gabriela José de \\ Almeida-Cincotto ${ }^{1}$, Ana Melero ${ }^{5}$, Marcos Antonio Corrêa ${ }^{1}$, Leila Aparecida Chiavacci ${ }^{1}$, Helena \\ Ribeiro $^{4}$, Teresa Garrigues 5 , Vera Lucia Borges Isaac ${ }^{1, *}$
}

\begin{abstract}
${ }^{1}$ Faculty of Pharmaceutical Sciences, Universidade Estadual Paulista, Araraquara, SP, Brazil, ${ }^{2}$ São Carlos Institute of Chemistry, Universidade de São Paulo, São Carlos, SP, Brazil, ${ }^{3}$ São Carlos School of Engineering, Universidade de São Paulo, São Carlos, SP, Brazil, ${ }^{4}$ Nanomedicine and Drug Delivery Systems group of iMed.UL, Faculty of Pharmacy, Universidade de Lisboa, Lisbon, Portugal, ${ }^{5}$ Department of Pharmacy and Pharmaceutic Technology, Faculty of Pharmacy, Universitat de València, Valencia, Spain
\end{abstract}

\begin{abstract}
Guava (Psidium guajava L.) is a native fruit of the American tropics with commercial applications for its taste, flavor and aroma. Numerous pharmacological uses have been described for it, such as the antiseptic effect of its leaves, the use of the fresh fruit and tea from its leaves for the treatment of diarrhea, dysentery, diabetes mellitus, and others. However, considering its rich composition, the guava also is a potential source of antioxidants to be used in the development of new formulations for cosmetic and/or dermatological applications, the main focus of this research. Herein, we describe the study of the phytochemical composition and the antioxidant activity of a guava extract prepared with non-toxic solvents aiming its use at biological applications. High performance liquid chromatography and mass spectrometry were employed to identify the major components, while thermoanalytical measurements and hot stage microscopy were used to assess the chemical stability of guava fruit extract. The antioxidant activity was also evaluated assessing the SOD-like activity and ABTS free radical scavenger. The results show that the extract is a rich source of phenolic compounds, such as quercetin, kaempferol, schottenol, among many others. All of the components found in guava extract exhibit biological effects according to the literature data, mainly antioxidant properties.
\end{abstract}

Uniterms: P. guajava L./phytochemistry. P. guajava L./use in cosmetics. P. guajava L./antioxidant/ chemical composition. P. guajava L/chemical stability. High Performance Liquid Chromatography.

\section{INTRODUCTION}

Some phytochemicals, such as phenolic compounds, carotenoids and vitamins, mainly ascorbic acid (C) and tocopherol (E), are effective free-radical scavengers (Jiménez-Escrig et al., 2001). These substances are likely to be effective in the reduction of the stroke and cancer incidence, already attributed to the consumption of fruits and vegetables (Beecher, 1999). They act mainly preventing the oxidative cell damage caused by the inactivation of free radicals generated by the metabolism,

\footnotetext{
*Correspondence: V. L. B. Isaac. Departamento de Fármacos e Medicamentos. Faculdade de Ciências Farmacêuticas. Universidade Estadual Paulista - UNESP. Rodovia Araraquara-Jaú, Km1 - 14800-903 - Araraquara - SP, Brazil. Phone number: 55(16) 3301-6979, Fax number: (16) 3322-0073. E-mail: lacos.unesp@gmail.com
}

inflammatory processes, environmental conditions, UV radiation etc (Dhalla, Temsah, Netticadan, 2000; Sander et al., 2004). Considering the importance of antioxidants in the human body, the regular consumption of significant amounts of fruits and vegetables has been promoted by specialists to prevent degenerative and chronic diseases (Jiménez-Escrig et al., 2001).

The application of antioxidants on the skin is also an important strategy to prevent damage aggravated by oxidative stress (Pinnell, 2003). A high concentration of antioxidants in skin care formulations allows the penetration of the epidermis and dermis. The main advantage of the topical administration when compared to the oral administration to treat and prevent skin conditions is the direct delivery of bioactive substances to the target area, thus eliminating concerns about systemic circulation 
(Meinke et al., 2010; Palombo et al., 2007). The cutaneous delivery of antioxidants is a complementary and well known treatment to prevent skin aging and to avoid dermal diseases, such as skin cancer (Sander et al., 2004; Pinnell, 2003; Dreher et al., 1998; Lopez-Torres et al., 1998).

Pinnell (2003) explains that antioxidants are an important alternative to protect the skin from photodamage, and should be associated with sunscreens. The latter being a useful tool, yet inadequate use prevents an ideal protection, causing an incomplete spectral barrier.

Considering fruits with antioxidant potential, the guava has been extensively cited. Other pharmacological activities have been described for the guava, such as an antiseptic effect, the treatment of diarrhea, dysentery, diabetes mellitus, and others (Gutiérrez, Mitchell, Solis, 2008). Also, its use is suggested among other agroindustrial products, as a food additive endowed with antimicrobial, texturizing and antioxidant activities (Ayala-Zavala et al., 2011; Ashraf et al., 2016), however, its use as a source of antioxidants for cosmetic application has so far not been studied in detail.

Guava crops are grown in tropical countries, being used as a food source, having commercial importance due to their exotic flavor and aroma (Soares et al., 2007). Besides, the fruit is a subtilized crop regarding to its potential biological properties (Willian, Haq, 2000). The paper "Global research on underutilized crops: an assessment of current activities and proposals for enhanced cooperation" also cites the guava since it is used almost exclusively for the food industry in the composition of jam and jellies.

Given its chemical value, this subtilized crop could be a source of an antioxidant extract for cosmetic and dermatological applications, thus contributing to the economic development of the agriculture and to the valorization of that fruit. Considering the great expansion of the cosmetic and beauty market and the benefits of antioxidants in the prevention of skin diseases, the guava is a commercially promising natural product. Nevertheless, the literature about its effects for cosmetic and dermatological use is rather limited. A great deal of research has shown and related its chemical composition and activities, based on the use of extracts prepared with organic toxic solvents (De Araújo et al., 2014; Thaipong et al., 2006), thus limiting its use in the health care industry. Also, the vast majority of the extracts studied were prepared from leaves and not from the hole fruit as suggested herein (Jaiarj et al., 1999; Lutterodt, Maleque, 1988, Oh et al., 2005).

With respect to the ethnopharmacological relevance, De Araújo et al. (2014) affirm that there is a large number of plant species cultivated in Brazil that have not yet been phytochemically or biologically evaluated, and thus, these authors propose the study of the composition of the guava.

Our research group has so far prepared, in an attempt to assess the guava crops and their chemical composition, several guava extracts from water-ethanol mixtures, of which the one obtained with $70 \%$ (vol.) ethanol was the richest in antioxidant agents (Chiari et al., 2012).

Thus, considering the antioxidant properties of guava extract and following the aims of our previous study (Chiari et al., 2012), we show herein the major components found in a hydroethanolic extract of the guava fruit and its antioxidant activity, proposing its use as a source of highly appreciated natural compounds for cosmetic and dermatological use.

High performance liquid chromatography and mass spectrometry were used to identify the major components, while thermoanalytical measurements and hot stage microscopy were used to assess the chemical stability of guava fruit extract. The antioxidant activity was also evaluated assessing the SOD-like and ABTS free radical scavenger activities.

\section{MATERIAL AND METHODS}

\section{Material}

Psidium guajava L. fruits, ethanol (LabSynth and Chemis, PA grade), the Superoxide dismutase (SOD) determination kit (Sigma-Aldrich), 2,2'-azino-bis-(3ehtylbenzothiazoline-6, 6'-sulfonic acid) diammonium salt (ABTS) (Sigma-Aldrich), Potassium persulfate (Synth), Methanol (HPLC grade), formic acid (HPLC grade), Ammonium formate (HPLC grade) were used. Internal standards (kaempferol 3-O-xylosyl-rutinoside, schottenol ferulate, 3-methoxysinensetin, quercetin 3-O-diglucoside, sesamolinol-4'-O- $\beta$-D-glucosyl (1->6)-O- $\beta$-D-glucoside, esculin, 3-sinapoylquinic acid, epicatechin 8-C-galactoside) were purchased from Sigma Aldrich and used following the manufacturer's guidelines.

\section{Methods}

\section{Plant}

P. guajava L. (Myrtaceae) ripe fruits, Paluma cultivar, were picked from trees in São Lourenço do Turvo, São Paulo (Brazil), in March 2009. Specimens were identified by the Herbarium (Herbário - Algas, Briófitas, Pteridófitas e Angiospermas) of the Universidade Estadual Paulista Júlio de Mesquita Filho-UNESP, as Psidium guajava SJRP 31237. 
Preparation of fruit extracts

The extract was prepared as described earlier (Chiari et al., 2012). The whole fresh guavas were disinfected in a sodium hypochlorite solution $(0.2 \%)$ for 2 hours and then rinsed in distilled water. Next, fruits were cut into small pieces, dried at $60{ }^{\circ} \mathrm{C}$ to constant weight (around 72 hours) in an air circulation chamber, and finely powdered in a knife mill (590 $\mu \mathrm{m}$ mesh size).

Samples of $50 \mathrm{~g}$ of the milled plant were percolated with $1.5 \mathrm{~L}$ of ethanol $(70 \% \mathrm{v} / \mathrm{v})$ at room temperature for 96 hours. Before the percolation process, $300 \mathrm{~mL}$ of ethanol $70 \%$ were left in contact with the fruit powder for 18 hours, after which $1.2 \mathrm{~L}$ of the mixture were added and the percolation process was carried out for 78 hours.

The extract was filtered through filter paper, concentrated under reduced pressure (MA-120, Marconi rotavapour) at $60{ }^{\circ} \mathrm{C}$, frozen, and freeze dried (Modulyo D Freeze Dryer, Thermo Scientific). The fruit extracts were stored in amber flasks at a controlled temperature $\left(5 \pm 2{ }^{\circ} \mathrm{C}\right)$ and assigned the term "E70 extract".

Chemical Characterization of the extract by HPLC and mass spectrometry

The Psidium guajava L. E70 extract was chemically characterized using HPLC and mass spectrometry.

\section{High Performance Liquid Chromatography}

HPLC separation was achieved using an Agilent 1290 HPLC system. The analyses were performed using a reverse phase column in an Agilent EC-C18.

The samples were eluted with water: methanol solution gradient, as shown in Table I, at a flow rate of $0.4 \mathrm{~mL} / \mathrm{min}$.

TABLE I - Gradient water: methanol used for HPLC separation

\begin{tabular}{ccc}
\hline Time (min) & $\begin{array}{c}\mathbf{H}_{\mathbf{2}} \mathbf{O} \text { (ammonium } \\
\text { formate } \mathbf{5} \mathbf{~ m M ,} \\
\text { formic acid } \mathbf{0 . 1} \%)\end{array}$ & Methanol \\
\hline 0 & 95 & 5 \\
2 & 50 & 50 \\
13 & 5 & 95 \\
15 & 5 & 95 \\
15.1 & 95 & 5 \\
25 & 95 & 5 \\
30 & 90 & 10 \\
\hline
\end{tabular}

Mass Spectrometry

All the mass spectra were acquired using an $\mathrm{AB}$ SCIEX TripleTOFTM 5600 LC/MS/MS System.
The MS was assessed using an IDA acquisition method with two experiments: the survey scan type (TOF-MS) and the dependent scan type (Product Ion) using -30 V of collision energy. Data were evaluated using the qualitative XIC manager in the PeakView ${ }^{\mathrm{TM}}$ software, being filtered based on mass error, retention time, isotope ratio $\%$ difference and library hit purity score (comparing with internal standards).

The conditions used were:

Ion source gas 1 (GC1): 50 psi

Ion source gas 2 (GC2): 50 psi

Curtain gas 1: 25 psi

Temperature: $450{ }^{\circ} \mathrm{C}$

Ion Spray Voltage (ISVF): -4500

\section{Thermoanalytical measurements and hot stage microscopy}

Thermoanalytical measurements were performed with a Q200 modulated DSC system (TA Instruments, New Castle, USA). The sample and the reference (air) were placed in aluminum Tzero pans, heated to $100^{\circ} \mathrm{C}$ at a rate of $2^{\circ} \mathrm{C} \mathrm{min}-1$, held isothermally for $1 \mathrm{~min}$, cooled to $20^{\circ} \mathrm{C}$ at $2{ }^{\circ} \mathrm{C} \mathrm{min}^{-1}$, held again isothermally for $15 \mathrm{~min}$, and then finally ramped to $100^{\circ} \mathrm{C}$ at $2{ }^{\circ} \mathrm{C} \mathrm{min}^{-1}$ before cooling down to ambient conditions. $2-5 \mathrm{mg}$ of extract gave the best result with regard to resolution, temperature, accuracy and attenuation. At least three replicates were obtained for each sample. The resulting DSC thermograms were analyzed using Universal Analysis 2000 (version 4.5, TA Instruments, New Castle, Del.). Reversed heat flow curves were used to detect the glass transition temperature for the extract.

A light microscope (Olympus BX51, Japan) equipped with a THMS350V (Linkam, Surrey, England) hot stage was used to visualize the behavior of the extract under stress conditions. The system was equipped with a digital camera (Olympus XC30, Japan) and the software Olympus Stream Essentials ${ }^{\circledR}$. Contact thermal microscopy was conducted by heating the samples from $20{ }^{\circ} \mathrm{C}$ to $100{ }^{\circ} \mathrm{C}$ using a $2{ }^{\circ} \mathrm{C} / \mathrm{min}$ heating rate.

\section{Antioxidant activity assessment}

The level of SOD-like activity in E70 was measured following the methodology provided with the manufacturer's kit (Sigma-Aldrich) and Ukeda et al. (1997). This SOD determination kit allows very convenient SOD assaying by utilizing Dojindo's highly water-soluble tetrazolium salt, WST-1 (2-(4-iodophenyl)3-(4-nitrophenyl)-5-(2,4-disulfophenyl)-2 $H$-tetrazolium, monosodium salt) that produces a water-soluble formazan dye upon reduction with a superoxide anion. The amount 
of the formazan dye produced in the reaction could be determined by a colorimetric method, at $450 \mathrm{~nm}$. The higher the antioxidant activity of the sample tested, the higher the scavenger of superoxide anion, and the lower the absorbance, since the water-soluble formazan dye is not produced.

Using the results, the scavenger percentage of the superoxide anion was determined, and a dose versus response curve was elaborated. Using Origin 7.0, the polynomial fit of the curve was carried out and the $\mathrm{IC}_{50}$ value was calculated.

The antioxidant activity was assessed also using the ABTS radical, with a spectrophotometric method previously described by Rufino et al. (2007). Stock solutions of ABTS $(7 \mathrm{mM})$ and potassium persulfate $(140 \mathrm{mM})$ were prepared in deionized water. Next, 88.0 $\mu \mathrm{L}$ of persulfate solution were added to $5.0 \mathrm{~mL}$ of the ABTS solution, and the mixture was kept away from light for 16 hours for the formation of the cation radical. The cation radical solution was diluted with ethanol until the absorbance at $734 \mathrm{~nm}$ reached $0.7 \pm 0.05$. Subsequently, $3.0 \mathrm{~mL}$ of the ethanolic solution containing the cation radical were added to $30 \mu \mathrm{L}$ of the sample (concentrations from 0 to $20 \mathrm{mg} / \mathrm{mL}$ ). After six minutes, the absorbance was measured at $734 \mathrm{~nm}$.

The antioxidant activity was expressed as $\mathrm{IC}_{50}$, defined as the final concentration of the tested sample required to scavenge $50 \%$ of the ABTS radical (the absorbance equivalent of the maximum amount of ABTS radical was determined using water to replace the sample in a negative control reaction). Linear regression analysis was used to calculate the $\mathrm{IC}_{50}$ values.

For both methods, ascorbic acid was used as control.

\section{RESULTS AND DISCUSSION}

Considering guava as a promising raw material for the application in cosmetic or dermatological fields, the detailed description of the components of the extract, mainly the non-volatile components is crucial for new studies and for the development of new products based on consolidated composition data. Psidium guajava L. fruit and its extracts were studied earlier with respect to their antioxidant activity and the amount of phenolic compounds (Chiari et al., 2012; Iha et al., 2008). However, there are few papers describing the components of a hydroethanolic extract of the fruit, suitable for cosmetic and dermatological use. The components of the entire fruit, but not of the fruit extract have been described. However, the major extracts related in the literature are prepared with unsuitable solvents for dermatological use or even toxic solvents. The description of the volatile compounds can also be found (Jiménez-Escrig, 2001; Soares et al., 2007; Chyau, Chen, Wu, 1992; Idstein, Schreier, 1985), as well the fruit oil composition (El-Ahmady, Ashour, Wink, 2013) can also be found.

The preparation of an extract using non-toxic solvents is crucial with regard to the toxicity of the formulation. Furthermore, the use of a green and toxicologically suitable solvent does not require further separation steps. Hence, the composition of the hydroethanolic guava extract was analyzed in an attempt to confirm the presence of the most important vegetal antioxidants. The total ion chromatogram obtained by negative-ion HPLC/MS/MS of E70 Psidium guajava L. extract is shown in Figure 1. The majority of the components of the extract eluted from 13 to 17 minutes, indicating the high concentration of methanolic solvent (95:5, methanol: water) was, as expected, the most suitable eluent for the components of the hydroethanolic extract. The substances were identified by negative-ion HPLC/MS/MS using internal standards, and many substances present in the extract were not identified. The choice of the substances to be screened in the extract was based on the antioxidant activity, i.e., several internal standards were analyzed using the same parameters (solvents and elution speed). The results (molecular weight and running time) were compared to these obtained for the guava sample extracts. The chromatographic profile revealed at least eight nonvolatile compounds, excluding quercetin derivatives. The identified compounds are shown in Table II. The molecular weights (MW) of the substances were in agreement with the phenol library of the equipment.

All the substances found in guava extract exhibit a wide variety of biologically beneficial activities, having an antioxidant effect. They are listed below and several of their properties are described.

Kaempferol is a flavonol with $\beta$-ring hydroxylation in the 4'-position. Kaempferol 3- $O$-xylosyl-rutinoside was identified in methanolic extracts of seven onion varieties (Lee, Zweigenbaum, Mitchell, 2013). It has an antioxidant as well as hypoglycemic effect (De Sousa et al., 2004; Park et al., 2006; Torel, Cillard, Cillard, 1986).

Quercetin is also a flavonol. Both, quercetin and kaempferol are found in onions and tea (De Vries et al., 1998), the two major sources of flavonols in the human diet.

Schottenol ferulate is described among sterol ferulates found in wheat, rye, and corn bran oils (Iwatsuki et al., 2003). It is one of the major phytosterols present in argan oil and in cactus seed oil (El Kharrassi et al., 2014). Many of the benefits described to be promoted by argan oil 


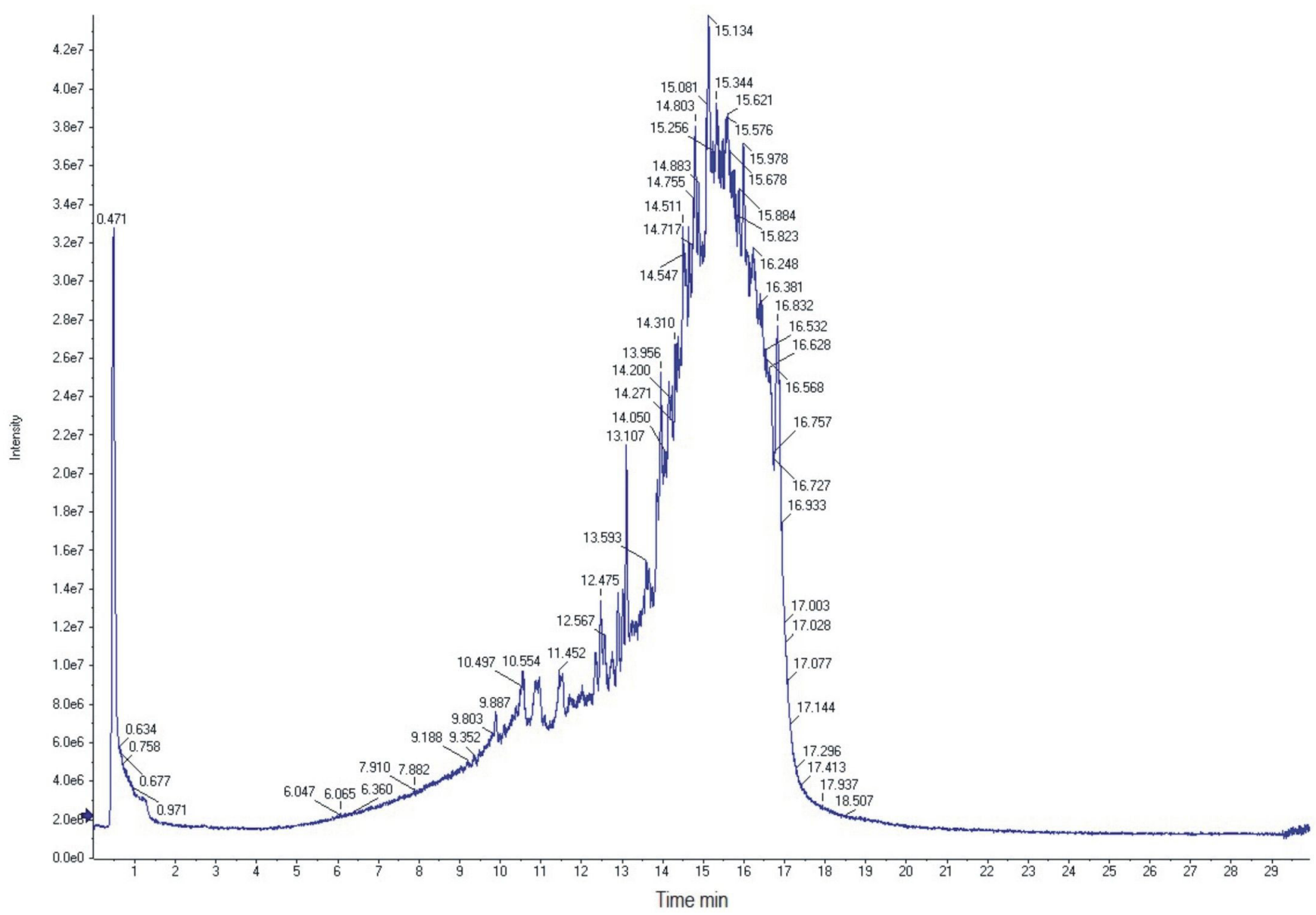

FIGURE 1 - Total ion chromatogram of E70 Psidium guajava L. extract obtained by negative-ion HPLC/MS/MS. Separation was achieved using injections of total extract, reversed-phase HPLC and gradient elution with water: methanol.

TABLE II - Phenolic compounds identified in E70 Psidium guajava L. extract by negative-ion HPLC/MS/MS

\begin{tabular}{lccccc}
\hline Substance & Formula & MW (Da) & $\begin{array}{c}\text { Extraction } \\
\text { mass (Da) }\end{array}$ & $\begin{array}{c}\text { Found at } \\
\text { mass (Da) }\end{array}$ & $\begin{array}{c}\text { Retention } \\
\text { time (min) }\end{array}$ \\
\hline Kaempferol 3- $O$-xylosyl-rutinoside & $\mathrm{C}_{15} \mathrm{H}_{10} \mathrm{O}_{7}$ & 302.04265 & 301.03538 & 301.03535 & 11.436 \\
Schottenol ferulate & $\mathrm{C}_{39} \mathrm{H}_{60} \mathrm{O}_{5}$ & 608.44408 & 607.4368 & 607.43706 & 13.902 \\
3-Methoxysinensetin & $\mathrm{C}_{18} \mathrm{H}_{14} \mathrm{O}_{8}$ & 358.06887 & 357.06159 & 357.06177 & 12.564 \\
$\begin{array}{l}\text { Quercetin 3-O-diglucoside and its derivatives } \\
\text { 3- } O \text {-acetillrhamnoside, 3- } O \text {-xylosyl-rutinoside, }\end{array}$ & $\mathrm{C}_{21} \mathrm{H}_{20} \mathrm{O}_{12}$ & 464.09548 & 463.0882 & 463.08849 & 10.174 \\
3-O-xyloside and 3-O-(6"-malonyl-glucoside) & & & & & \\
Sesamolinol 4'-O- $\beta$-D-glucosyl (1->6)-O-b- & $\mathrm{C}_{10} \mathrm{H}_{12} \mathrm{O}_{3}$ & 180.07864 & 179.07137 & 179.0712 & 12.153 \\
$\begin{array}{l}\text { D-glucoside } \\
\text { Esculin }\end{array}$ & $\mathrm{C}_{17} \mathrm{H}_{26} \mathrm{O}_{4}$ & 294.18311 & 293.17583 & 293.17612 & 13.12316 .546$, \\
3-Sinapoylquinic acid & $\mathrm{C}_{17} \mathrm{H}_{20} \mathrm{O}_{9}$ & 368.11073 & 367.10346 & 367.10463 & 1.178 \\
(-)- Epicatechin 8- $C$-galactoside & $\mathrm{C}_{15} \mathrm{H}_{14} \mathrm{O}_{7}$ & 306.07395 & 305.06668 & 305.06865 & 8.8019 .042 \\
\hline
\end{tabular}

are attributed to schottenol, and besides its hypolipemiant effects, antioxidant effects can also be cited (Drissi et al., 2004) as well as its protective role in the modulation of the cholesterol metabolism (El Kharrassi et al., 2014).
3-Methoxysinensetin is a polymethoxyflavone found in sweet orange (Citrus sinensis) peel, exhibiting a variety of effects, such as antiinflammatory, anticarcinogenic, and antiatherogenic properties (Li et al., 2006). 
Sesamolinol 4'-O-b-D-glucosyl (1->6)-O-b-Dglucoside was found in $P$. guajava L. extract as a novel antioxidant isolated from sesame seeds and it was described as more active than Vitamin $\mathrm{E}$ through in vitro anti-oxidative assays using rat liver microsomes (Osawa et al., 1985).

Multiple biological activities are attributed to esculin such as the inhibition of xanthine oxidase activity, antioxidant activity, antitumor activity and an inhibitory effect on the growth of human breast cancer cells (Duncan, Flint, Stewart, 1998; Wang et al., 2002). Zhao et al. (2007) also described anti-oxidative and anti-apoptotic properties of esculin, being proposed as an alternative to the treatment of progressive neurodegenerative diseases such as Parkinson's disease. Moreover, Kaneko et al. (2007) suggested the inhibitory effects on induced oxidative DNA damage and carcinogenesis.

3-Sinapoylquinic acid was found in green Robusta coffee beans (Jaiswal et al., 2010) and in Gardeniae fructus, traditionally used as a Chinese herbal medicine (Clifford et al., 2010). It is a chlorogenic acid with antioxidant effects, thus, it might contribute to the prevention of chronic diseases such as cardiovascular disease (Olthof, Hollman, Katan, 2001).

(-)-Epicatechin 8-C-galactoside was earlier isolated from cacao liquor and demonstrated an antioxidant effect (Hatano et al., 2002).

Quercetin 3-O-acetilrhamnoside, quercetin 3-O-(6"malonyl-glucoside), quercetin 3-O-xyloside, quercetin 3-O-diglucoside and quercetin 3-O-xylosyl-rutinoside were found in Psidium guajava L. extract. Quercetin has been extensively studied and many biological properties, namely being antiperoxidative, antioxidant and antihistaminic, have been attributed to it (Kahraman et al., 2003).

The identification of these antioxidant substances in the extract indicates the effectiveness of the extraction method and solvent ( 70 vol\% hydroethanolic solution) used, having provided a wide variety of phenolic compounds earlier identified in many plant specimens.

\section{Thermoanalytical measurements and hot stage microscopy}

DSC is a physical characterization method applied to the study of the thermal behavior of many materials, used to characterize novel and promising extracts. DSC thermograms and their enthalpy changes are important indicators of the effect of storage conditions on guava extract, able to forecast the future quality of the extract.

Figure 2 shows a typical modulated DSC thermogram depicting the onset of glass transition and the enthalpy peak observed for the extract between $20^{\circ} \mathrm{C}$ and $100{ }^{\circ} \mathrm{C}$. In this study, the glass transition $(\mathrm{Tg})$ value of the extract was low $\left(0.198 \pm 0.875 \mathrm{~J} /\left(\mathrm{g} .{ }^{\circ} \mathrm{C}\right)\right.$, with an onset point of around $57.60{ }^{\circ} \mathrm{C}$ and a midpoint of $60.57^{\circ} \mathrm{C}$. A dramatic change in the structure starts with the loss of the water. Water loss might occur, but it is only at $90^{\circ} \mathrm{C}$ that the water has totally evaporated.

Figure 2 shows that guava extract is a hygroscopic extract, due to the presence of a main endothermic peak at $90{ }^{\circ} \mathrm{C}$, consistent with the water evaporation. This result is in agreement with previous results, demonstrating that guava extract contains numerous polar sites to bind water molecules (Rahman, Al-Sadi, Guizani, 2008).

Thermo-microscopic investigations of the extract at a scanning rate of $2{ }^{\circ} \mathrm{C} / \mathrm{min}$, as illustrated in Figure 2, show, at approximately $60{ }^{\circ} \mathrm{C}$, small droplets of water on the surface of the extract, indicating that the water was partially eliminated from the extract during the solid-liquid transition, accumulating on the surface of the extract and then evaporated. This process was completed when reaching about $90^{\circ} \mathrm{C}$. The main endothermic peak on the total heat flow curve was due to further loss of water.

It was demonstrated that extract transition occurs, preferentially at $60{ }^{\circ} \mathrm{C}$, thus the approach used for the improvement of the chemical and physical stability should incorporate the guava extract in topical dosage forms below $50{ }^{\circ} \mathrm{C}$ in order to reduce the changes during manufacture.

Due to the nature and stability of guava extract, aqueous cold processed-based topical dosage forms could be an appropriate approach intended for dermatological use. These systems can be used as carriers for therapeutic agents such as extracts, since they display suitable characteristics. Cold process methods and aqueous-based vehicles allow a decrease in the total production costs (Raposo et al., 2014).

\section{Antioxidant activity assessment}

The determination of antioxidant activity of E70 measured by means of the determination of the level of SOD-like activity allowed the construction of the dose versus response curve shown in Figure 3.

According to our results, the concentration to inhibit $50 \%$ of the WST-1 formazan crystals $\left(\mathrm{IC}_{50}\right)$ was $0.1904 \pm 0.0039 \mathrm{mg} / \mathrm{mL}$. It was also observed that when the concentration of E70 increased, the inhibition percentage of the formazan crystals increased, indicating E70 is able to act as the antioxidant enzyme superoxide dismutase. 


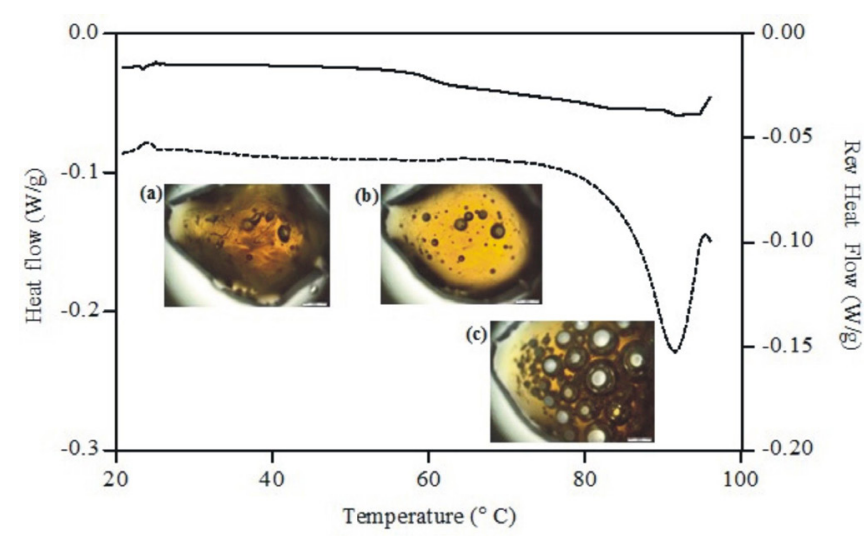

FIGURE 2 - Typical total (dots) and reversed (line) heat flow curves for guava extract. DSC thermogram of extract with photomicrographs of guava extract during a heating program for $2{ }^{\circ} \mathrm{C} / \mathrm{min}$ between $20^{\circ} \mathrm{C}$ and $100^{\circ} \mathrm{C}$, at $20^{\circ} \mathrm{C}$ (a), at $60{ }^{\circ} \mathrm{C}$ (b) and at $90^{\circ} \mathrm{C}(\mathrm{c})($ Scale bar $=200 \mu \mathrm{m})$.

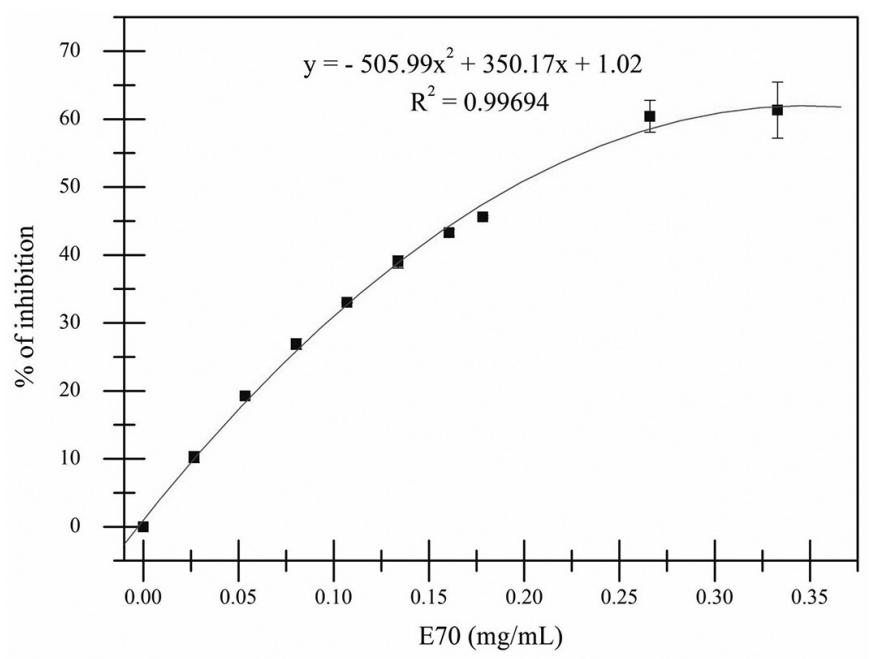

FIGURE 3 - Inhibition percentage of WST-1 formazan by the E70 extract.

For ascorbic acid the $\mathrm{IC}_{50}$ determined was 25.69 $\mu \mathrm{g} / \mathrm{mL}$.

In agreement with our results, Chen and Yen (2007) evaluated the ability of an aqueous extract (prepared with boiling water) of dried fruits of guava in scavenger superoxide anions. Besides the fact that the antioxidant potential was also proved in their study, $\mathrm{IC}_{50}$ was near to $0.450 \mathrm{mg} / \mathrm{mL}$, approximately 2.4 times higher than for the E70 extract, confirming that the extraction with ethanol $(70 \%)$ is an effective manner to extract guava phenolic compounds, using a nontoxic solvent, being more efficient than the extraction with water, and which does not consume energy.

The substances found in the extract are effective antioxidants to maintain the homeostasis in the living environment. The extraction of these substances from vegetable sources for biological uses in animals has been extensively explored and is on the increase. The antioxidant activity results showed the substances kept their activity for application in pharmaceutical formulations.

To reinforce this result, the radical ABTS scavenger activity of E70 was assessed. Figure 4 shows the dose versus response curve correlating the concentration of E70 and the scavenging of the free radical.

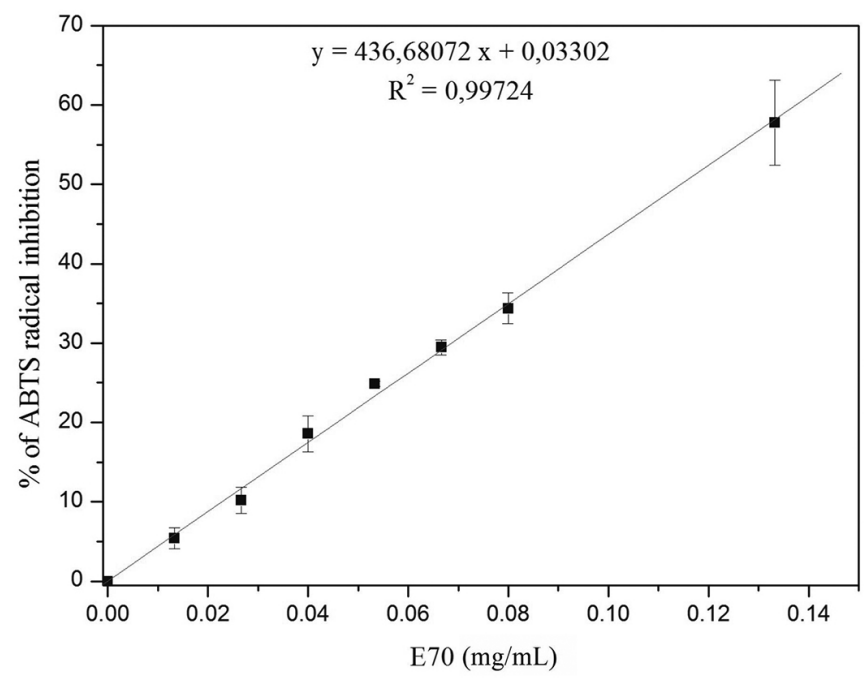

FIGURE 4 - ABTS scavenger activity (\%) of E70 extract.

The $\mathrm{IC}_{50}$ calculated by means of the equation generated with the linear regression of the curve was $0.115 \pm 0.007 \mathrm{mg} / \mathrm{mL}$. This value is even smaller than the $\mathrm{IC}_{50}$ calculated for the SOD like activity. Ascorbic acid was also assessed as antioxidant control, the $\mathrm{IC}_{50}$ value was of $1.27 \mu \mathrm{g} / \mathrm{mL}$.

\section{CONCLUSION}

Our results show that Psidium guajava L. hydroethanolic extract contains many compounds earlier described as promising substances related to promoting health benefits. It can be noted that the substances found in guava extract, prepared with non-toxic solvents, showed antioxidant activity, that could be considered similar to the superoxide dismutase enzyme. Also, the extract is considered stable at temperatures below $60{ }^{\circ} \mathrm{C}$, being a relevant alternative as antioxidant compound to be used in cosmetics and health care products, aiming to protect the skin from environmental conditions.

\section{ACKNOWLEGMENTS}

The authors wish to thank Predilecta Indústria de 
Alimentos for the donation of guava fruits and Capes, CNPq, PADC-FCF-UNESP, FUNDUNESP for the financial support. The authors are also grateful to Timothy John C. Roberts and Ralph Wilk in revising the English text.

\section{REFERENCES}

ASHRAF, A.; SARFRAZ, R.A.; RASHID, M.A.; MAHMOOD, A.; SHAHID, M.; NOOR, N. Chemical composition, antioxidant, antitumor, anticancer and cytotoxic effects of Psidium guajava leaf extracts. Pharm. Biol., v.54, n.10, p.1971-1981, 2016.

AYALA-ZAVALA, J.F.; VEGA-VEGA, V.; ROSASDOMÍNGUEZ, C.; PALAFOX-CARLOS, H.; VILLARODRIGUEZ, J.A.; SIDDIQUI, M.W.; DÁVILA-AVIÑA, J.E.; GONZÁLEZ-AGUILAR, G.A. Agro-industrial potential of exotic fruit byproducts as a source of food additives. Food. Res. Int., v.44, n.7, p.1866-1874, 2011.

BEECHER, G.R. Phytonutrients' role in metabolism: effects on resistance to degenerative processes. Nutr. Rev., v.57, n.9, pt. 2, p.S3-6, 1999.

CHEN, H.-Y.; YEN, G.-C. Antioxidant activity and free radicalscavenging capacity of extracts from guava (Psidium guajava L.) leaves. Food Chem., v.101, n.2, p.686-694, 2007.

CHIARI, B.G.; SEVERI, J.A.; PAULI-CREDENDIO, P.A.D.; SYLOS, C.M.D.; VILEGAS, W.; CORRÊA, M.A.; ISAAC, V.L.B. Assessment of the chemical profile, polyphenol content and antioxidant activity in extracts of Psidium guajava L. fruits. Int. J. Pharm. Pharm. Sci., v.4, p.331336, 2012.

CHYAU, C.C.; CHEN, S.Y.; WU, C.M. Differences of volatile and nonvolatile constituents between mature and ripe guava (Psidium guajava Linn.) fruits. J. Agr. Food Chem., v.40, n.5, p.846-849, 1992.

CLIFFORD, M.N.; WU, W.; KIRKPATRICK, J.; JAISWAL, R.; KUHNERT, N. Profiling and characterisation by liquid chromatography/multi-stage mass spectrometry of the chlorogenic acids in Gardeniae fructus. Rapid Commun. Mass Spectrom., v.24, n.21, p.3109-3120, 2010.
DE ARAÚJO, A.A.; SOARES, L.A.L.; ASSUNÇÃO FERREIRA, M.R.; DE SOUZA NETO, M.A.; DA SILVA, G.R.; DE ARAÚJO, R.F.; GUERRA, G.C.B.; DE MELO, M.C.N. Quantification of polyphenols and evaluation of antimicrobial, analgesic and anti-inflammatory activities of aqueous and acetone-water extracts of Libidibia ferrea, Parapiptadenia rigida and Psidium guajava. $J$. Ethnopharmacol., v.156, p.88-96, 2014.

DE SOUSA, E.; ZANATTA, L.; SEIFRIZ, I.; CRECZYNSKIPASA, T.B.; PIZZOLATTI, M.G.; SZPOGANICZ, B.; SILVA, F.R.M.B. Hypoglycemic effect and antioxidant potential of kaempferol-3,7-O-(alpha)-dirhamnoside from Bauhinia forficata leaves. J. Nat. Prod., v.67, n.5, p.829832, 2004.

DE VRIES, J.H.; HOLLMAN, P.C.; MEYBOOM, S.; BUYSMAN, M.N.; ZOCK, P.L.; VAN STAVEREN, W.A.; KATAN, M.B. Plasma concentrations and urinary excretion of the antioxidant flavonols quercetin and kaempferol as biomarkers for dietary intake. Am. J. Clin. Nutr., v.68, n.1, p.60-65, 1998.

DHALLA, N.S.; TEMSAH, R.M.; NETTICADAN, T. Role of oxidative stress in cardiovascular diseases. J. Hypertens., v.18, n.6, p.655-673, 2000.

DREHER, F.; GABARD, B.; SCHWINDT, D.A.; MAIBACH, H.I. Topical melatonin in combination with vitamins $\mathrm{E}$ and $\mathrm{C}$ protects skin from ultraviolet-induced erythema: a human study in vivo: Protection from UV-induced erythema. Brit. J. Dermatol., v.139, n.2, p.332-339, 1998.

DRISSI, A.; GIRONA, J.; CHERKI, M.; GODÀS, G.; DEROUICHE, A.; EL MESSAL, M.; SAILE, R.; KETTANI, A.; SOLÀ, R.; MASANA, L.; ADLOUNI, A. Evidence of hypolipemiant and antioxidant properties of argan oil derived from the argan tree (Argania spinosa). Clin. Nutr., v.23, n.5, p.1159-1166, 2004.

DUNCAN, S.H.; FLINT, H.J.; STEWART, C.S. Inhibitory activity of gut bacteria against Escherichia coli $\mathrm{O} 157$ mediated by dietary plant metabolites. FEMS Microbiol. Lett., v.164, n.2, p.283-288, 1998. 
EL KHARRASSI, Y.; SAMADI, M.; LOPEZ, T.; NURY, T.; EL KEBBAJ, R.; ANDREOLETTI, P.; EL HAJJ, H.I.; VAMECQ, J.; MOUSTAID, K.; LATRUFFE, N.; EL KEBBAJ, M.S.; MASSON, D.; LIZARD, G.; NASSER, B.; CHERKAOUI-MALKI, M. Biological activities of Schottenol and Spinasterol, two natural phytosterols present in argan oil and in cactus pear seed oil, on murine miroglial BV2 cells. Biochem. Biophys. Res. Commun., v.446, n.3, p.798-804, 2014.

EL-AHMADY, S.H.; ASHOUR, M.L.; WINK, M. Chemical composition and anti-inflammatory activity of the essential oils of Psidium guajava fruits and leaves. J. Essent. Oil Res., v.25, n.6, p.475-481, 2013.

GUTIÉRREZ, R.M.P.; MITCHELL, S.; SOLIS, R.V. Psidium guajava: A review of its traditional uses, phytochemistry and pharmacology. J. Ethnopharmacol., v.117, n.1, p.127, 2008.

HATANO, T.; MIYATAKE, H.; NATSUME, M.; OSAKABE, N.; TAKIZAWA, T.; ITO, H.; YOSHIDA, T. Proanthocyanidin glycosides and related polyphenols from cacao liquor and their antioxidant effects. Phytochemistry, v.59, n.7, p.749$758,2002$.

IDSTEIN, H.; SCHREIER, P. Volatile constituents from guava (Psidium guajava L.) fruit. J. Agr. Food Chem., v.33, n.1, p.138-143, 1985.

IHA, S.M.; MigliATO, K.F.; VELLOSA, J.C.R.; SACRAMENTO, L.V.S.; PIETRO, R.C.L.R.; ISAAC, V.L.B.; BRUNETTI, I.L.; CORRÊA, M.A.; SALGADO, H.R.N. Estudo fitoquímico de goiaba (Psidium guajava L.) com potencial antioxidante para o desenvolvimento de formulação fitocosmética. Rev. Bras. Farmacogn., v.18, n.3, p.387-393, 2008.

IWATSUKI, K.; AKIHISA, T.; TOKUDA, H.; UKIYA, M.; HIGASHIHARA, H.; MUKAINAKA, T.; IIZUKA, M.; HAYASHI, Y.; KIMURA, Y.; NISHINO, H. Sterol ferulates, sterols, and 5-alk(en)ylresorcinols from wheat, rye, and corn bran oils and their inhibitory effects on Epstein-Barr virus activation. J. Agr. Food Chem., v.51, n.23, p.66836688, 2003.

JAIARJ, P.; KHOOHASWAN, P.; WONGKRAJANG, Y.; PEUNGVICHA, P.; SURIYAWONG, P.; SARAYA, M.L.; RUANGSOMBOON, O. Anticough and antimicrobial activities of Psidium guajava Linn. leaf extract. $J$. Ethnopharmacol., v.67, n.2, p.203-212, 1999.
JAISWAL, R.; PATRAS, M.A.; ERAVUCHIRA, P.J.; KUHNERT, N. Profile and Characterization of the Chlorogenic Acids in Green Robusta Coffee Beans by LC$\mathrm{MS}^{n}$ : Identification of Seven New Classes of Compounds. J. Agr. Food Chem., v.58, n.15, p.8722-8737, 2010.

JIMÉNEZ-ESCRIG, A.; RINCÓN, M.; PULIDO, R.; SAURACALIXTO, F. Guava Fruit (Psidium guajava L.) as a New Source of Antioxidant Dietary Fiber. J. Agr. Food Chem., v.49, n.11, p.5489-5493, 2001.

KAHRAMAN, A.; ERKASAP, N.; KÖKEN, T.; SERTESER, M.; AKTEPE, F.; ERKASAP, S. The antioxidative and antihistaminic properties of quercetin in ethanol-induced gastric lesions. Toxicology, v.183, n.1-3, p.133-142, 2003.

KANEKO, T.; TAHARA, S.; TAKABAYASHI, F. Inhibitory effect of natural coumarin compounds, esculetin and esculin, on oxidative DNA damage and formation of aberrant crypt foci and tumors induced by 1,2-dimethylhydrazine in rat colons. Biol. Pharm. Bull., v.30, n.11, p.2052-2057, 2007.

LEE, J.; ZWEIGENBAUM, J.; MITCHELL, A.E. Nontargeted unknown LC (ESI-)-Q/TOF MS approaches for food verification. In: TUNICK, M.H.; ONWULATA, C.I. (Eds.). Physical methods in food analysis. Washington, DC: American Chemical Society, 2013. p.17-29.

LI, S., LO, C.-Y., HO, C.-T. Hydroxylated polymethoxyflavones and methylated flavonoids in sweet orange (Citrus sinensis) peel. J. Agr. Food Chem., v.54, n.12, p.4176-4185, 2006.

LOPEZ-TORRES, M.; THIELE, J.J.; SHINDO, Y.; HAN, D.; PACKER, L. Topical application of $\alpha$-tocopherol modulates the antioxidant network and diminishes ultraviolet-induced oxidative damage in murine skin. Brit. J. Dermatol., v.138, n.2, p.207-215, 1998.

LUTTERODT, G.D.; MALEQUE, A. Effects on mice locomotor activity of a narcotic-like principle from Psidium guajava leaves. J. Ethnopharmacol., v.24, n.2-3, p.219-231, 1988.

MEINKE, M.C.; DARVIN, M.E.; VOLLERT, H.; LADEMANN, J. Bioavailability of natural carotenoids in human skin compared to blood. Eur. J. Pharm. Biopharm., v.76, n.2, p.269-274, 2010.

OH, W.K.; LEE, C.H.; LEE, M.S.; BAE, E.Y.; SOHN, C.B.; $\mathrm{OH}, \mathrm{H}$.; KIM, B.Y.; AHN, J.S. Antidiabetic effects of extracts from Psidium guajava. J. Ethnopharmacol., v.96, n.3, p.411-415, 2005. 
OLTHOF, M.R.; HOLLMAN, P.C.; KATAN, M.B. Chlorogenic acid and caffeic acid are absorbed in humans. J. Nutr., v.131, n.1, p.66-71, 2001.

OSAWA, T.; NAGATA, M.; NAMIKI, M.; FUKUDA, Y. Sesamolinol, a Novel Antioxidant Isolated from Sesame Seeds. Agr. Biol. Chem. Tokyo, v.49, n.11, p.3351-3352, 1985.

PALOMBO, P.; FABRIZI, G.; RUOCCO, V.; RUOCCO, E.; FLUHR, J.; ROBERTS, R.; MORGANTI, P. Beneficial long-term effects of combined oral/topical antioxidant treatment with the carotenoids lutein and zeaxanthin on human skin: a double-blind, placebo-controlled study. Skin Pharmacol. Physiol., v.20, n.4, p.199-210, 2007.

PARK, J.S.; RHO, H.S.; KIM, D.H.; CHANG, I.S. Enzymatic preparation of kaempferol from green tea seed and its antioxidant activity. J. Agr. Food Chem., v.54, n.8, p.29512956, 2006.

PINNELL, S.R. Cutaneous photodamage, oxidative stress, and topical antioxidant protection. J. Am. Acad. Dermatol., v.48, n.1, p.1-22, 2003.

RAHMAN, M.S.; AL-SAIDI, G.S.; GUIZANI, N. Thermal characterisation of gelatin extracted from yellowfin tuna skin and commercial mammalian gelatin. Food Chem., v.108, n.2, p.472-481, 2008.

RAPOSO, S.; SALGADO, A.; ECCLESTON, G.; URBANO, M.; RIBEIRO, H.M. Cold processed oil-in-water emulsions for dermatological purpose: formulation design and structure analysis. Pharm. Dev. Technol., v.19, n.4, p.417429, 2014.

RUFINO, M.S.M.; ALVES, R.E.; BRITO, E.S.; DE MORAIS, S.M.; SAMPAIO, C.G.; PÉREZ-JIMÉNEZ, J.; SAURACALIXTO, F.D. Determinação da Atividade Antioxidante Total em Frutas pela Captura do Radical Livre ABTS. Comunicado Técnico on line (EMBRAPA), n.128, 2007.

SANDER, C.S.; CHANG, H.; HAMM, F.; ELSNER, P.; THIELE, J.J. Role of oxidative stress and the antioxidant network in cutaneous carcinogenesis. Int. J. Dermatol., v.43, n.5, p.326-335, 2004.
SOARES, F.D.; PEREIRA, T.; MAIO MARQUES, M.O.; MONTEIRO, A.R. Volatile and non-volatile chemical composition of the white guava fruit (Psidium guajava) at different stages of maturity. Food Chem., v.100, n.1, p.15-21, 2007.

THAIPONG, K.; BOONPRAKOB, U.; CROSBY, K.; CISNEROS-ZEVALLOS, L.; HAWKINS BYRNE, D. Comparison of ABTS, DPPH, FRAP, and ORAC assays for estimating antioxidant activity from guava fruit extracts. $J$. Food. Compos. Anal., v.19, n.6-7, p.669-675, 2006.

TOREL, J.; CILlARD, J.; CILlARD, P. Antioxidant activity of flavonoids and reactivity with peroxy radical. Phytochemistry, v.25, n.2, p.383-385, 1986.

UKEDA, H.; MAEDA, S.; ISHII, T.; SAWAMURA, M. Spectrophotometric assay for superoxide dismutase based on tetrazolium salt 3'-\{1-[(phenylamino)-carbonyl $]-3,4$ tetrazolium $\}$-bis(4-methoxy-6-nitro)benzenesulfonic acid hydrate reduction by xanthine-xanthine oxidase. Anal. Biochem., v.251, n.2, p.206-209, 1997.

WANG, C.J.; HSIEH, Y.J.; CHU, C.Y.; LIN, Y.L.; TSENG, T.H. Inhibition of cell cycle progression in human leukemia HL-60 cells by esculetin. Cancer Lett., v.183, n.2, p.163$168,2002$.

WILLIAMS, J.T.; HAQ, N. Global research on underutilised crops an assessment of current activities and proposals for enhanced cooperation, 2000. Available at: $<$ http://www.fao. org/docs/eims/upload/216780/uoc_assessment_current activities.pdf $>$. Accessed on: Jul. 2016.

ZHAO, D.-L.; ZOU, L.-B.; LIN, S.; SHI, J.-G.; ZHU, H.-B. Anti-apoptotic effect of esculin on dopamine-induced cytotoxicity in the human neuroblastoma SH-SY5Y cell line. Neuropharmacology, v.53, n.6, p.724-732, 2007.

Received for publication on $20^{\text {th }}$ July 2016 Accepted for publication on $06^{\text {th }}$ October 2016 